\title{
Relevansi Kosep Belajar Menurut Ki Hadjar Dewantara dengan Pendidikan Agama Islam
}

\author{
Achmad Krisbiyanto
}

\begin{abstract}
Ki Hajar Dewantara an educational leaders in Indonesia. Ki Hajar Dewantara have learned concepts that are conservative and make the learner as central to the learning process. Based on this background, it is necessary to learn Ki Hajar Dewantara for-mulation appropriate to the context of Islamic Education.The purpose of this study is to explore the concept of learning by Ki Hajar Dewantara and express their relevance to Islamic education.

This study is a literature research. Material object of this research is to learn the re- sult of thinking Ki Hajar Dewantara. The approach used is a psychological approach. This is a qualitative study, using the document as a source of research and power analysis method is content analysis.

The study found that learning by Ki Hajar Dewantara is a liberating learning learners. Liberate means that learners are developed in accordance with the talent and interest is based on the existing potential that idea, feeling, and intention. The development is expected to transform into a human learners can master yourself, independent, with- out having to depend on others. The role of educators is to guide, direct, and motivate learners with basic affection. Learners is central to learning activities are carried out. The method used in the learning process should be based on compassion. It was also found that the study in view of Ki Hajar Dewantara relevant to Islamic education. It can be seen from the concept study developed by Ki Hajar Dewantara not contrary to Islamic education. Only the term he uses a different but similar meaning.
\end{abstract}

Keywords: Learning, Ki Hajar Dewantara, Islamic Education.

\section{PENDAHULUAN}

Kata kunci dalam setiap usaha pendidikan, Proses belajar merupakan proses perubahan menuju tujuan pembelajaran, sebagai interaksi dengan lingkunganya. Belajar merupakan kehingga jika tanpa proses belajar maka pendidikan tidak akan terlaksana secara baik. Tinggi rendahnya kualitas perkembangan manusia merupakan hasil nyata dari proses belajar, dan tentunya sangat menentukan tingkat peradaban atau derajat manusia. Belajar dalam pendidikan formal merupakan kegiatan pokok yang menentukan berhasil atau tidaknya pencapain tujuan pendidikan. Oleh karena itu, belajar perlu direncanakan dengan mempertimbangkan aspek yang mempengaruhi pencapaian tujuan pendidikan.

Menurut Ki Hadjar Dewantara manusia memiliki daya jiwa yaitu cipta, karsa, dan karya. Pengembangan manusia seutuhnya menuntut pengembangan semua daya secara seimbang. Pengembangan yang terlalu menitikberatkan pada satu daya saja akan menghasilkan ketidakutuhan perkembangan sebagai manusia. Ki Hadjar Dewantara mengatakan bahwa pendidikan yang menekankan pada aspek intelektual belaka hanya akan menjauhkan peserta didik dari masyarakatnya. Sedangkan dalam kurikulum 2013 peserta didik didorong agar mampu melakukan observasi, bertanya, bernalar, dan mengkomunikasikan (mempresentasikan) yang telah diperoleh setelah menerima materi pembelajaran. Hal tersebut tentunya sangat relevan dengan tujuan yang di inginkan oleh Ki Hadjar Dewantara yaitu membentuk manusia merdeka, manusia yang tidak tergantung dengan orang lain dan mampu mempertanggungjawabkan perbuatanya. 
Sementara itu, Pendidikan Agama Islam di sekolah atau madrasah bertujuan untuk menumbuhkan dan meningkatkan keimanan. Hal tersebut dilakukan melalui pemberian dan pemupukan pengetahuan, penghayatan, pengamalan, serta pengalaman tentang agama Islam sehingga menjadi muslim yang berkembang dalam hal keimanan, ketakwaan, berbangsa, serta untuk melanjutkan pada jenjang pendidikan yang lebih tinggi. Pendidikan agama Islam juga mempunyai tujuan pembentukan kepribadian muslim, yaitu suatu kepribadian yang seluruh aspeknya dijiwai oleh ajaran Islam.

Untuk mendukung terciptanya proses pembelajaran yang baik, maka harus ada sinkronisasi antara kurikulum 2013, pendidikan agama islam, dan proses pembentukan kepribadian peserta didik yang direncanakan dan disusun sejak dini. Maka dari itu penulis mengkaji disiplin ilmu tersebut, Konsep Belajar menurut Ki Hadjar Dewantara dan Relevansinya dengan Pendidikan Agama Islam. Atas hal tersebut: Bagaimana konsep belajar menurut Ki Hadjar Dewantara?; Bagaimana pula relevansi konsep belajar menurut Ki Hadjar Dewantara dengan pendidikan agama Islam?

\section{KAJIAN TEORI}

\section{Konsep Belajar}

Belajar merupakan suatu proses usaha yang dilakukan seseorang untuk memperoleh suatu perubahan tingkah laku yang baru secara keseluruhan, sebagai hasil pengalamannya sendiri dalam interaksi dengan lingkungannya. Pendapat lain mengungkapkan bahwa belajar merupakan perubahan yang relatif menetap dalam tingkah laku, yang terjadi sebagai suatu hasil dari latihan atau pengalaman. Berlangsungnya proses belajar tidak terlepas dari komponen yang ada di dalamnya. Komponen proses pembelajaran yaitu, peserta didik, guru, tujuan pembelajaran, materi, metode, media dan evalusi. Hal tersebut diperjelas dalam ulasan berikut.

Peserta didik merupakan sosok anak yang membutuhkan bimbingan dari orang yang lebih berwibawa. Sebagai anak, umumnya mereka masih dalam kondisi lemah, kurang berdaya, dan belum bisa mandiri sehingga masih membutuhkan orang lain.

Tugas pendidik di lembaga formal adalah mendeskripsikan, menerangkan, memberi pertanyaan dan mengevaluasi. Tugas tersebut akan menimbulkan perubahan pada masyarakat, walaupun tidak dapat dilihat dalam waktu yang singkat.

Tujuan belajar bagi peserta didik adalah mengembangkan potensi dalam diri yang meliputi ranah kognitif, afektif dan psikomotorik. Metode adalah cara yang digunakan pendidik dalam mengadakan interaksi atau hubungan dengan siswa pada saat berlangsungnya proses belajar siswa.

Media belajar adalah segala sesuatu yang dapat digunakan untuk menyalurkan pesan dari pengirim ke penerima sehingga dapat merangsang pikiran, perasaan, perhatian, dan kompetensi serta perhatian peserta didik sehingga proses belajar terjadi.

Evaluasi merupakan proses memberikan atau menentukan nilai kepada objek tertentu berdasarkan suatu kriteria tertentu. Evaluasi belajar merupakan penilaian kegiatan dan kemajuan belajar peserta didik yang dilakukan secara berkala berbentuk ujian, hasil praktik, tugas harian, atau pengamatan oleh pendidik. Pembobotan masing-masing unsur penilaian ditetapkan berdasarkan KKM sesuai dengan kurikulum sekolah.

\section{Pendidikan Agama Islam}

Secara tekstual pendidikan Islam adalah pendidikan yang berdasarkan ajaran Islam, yakni bersumber dari Al-Quran dan Sunah. Pendidikan Islam membimbing jasmani dan rohani peserta didik berdasarkan norma-norma agama Islam menuju kepada terbentuknya kepribadian 
utama menurut ukuran-ukuran Islam. Hasil dari pendidikan Agama Islam tersebut yaitu manusia muslim yang terus berkembang dalam hal keimanan, ketakwaannya, berbangsa, serta untuk dapat melanjutkan pada jenjang pendidikan yang lebih tinggi. Pendidikan Agama Islam juga mempunyai tujuan pembentukan kepribadian muslim, yaitu suatu kepribadian yang seluruh aspeknya dijiwai oleh ajaran Islam.

Pendidikan agama islam di sekolah maupun madrasah memiliki aspek kajian. Terdapat tiga aspek dalam pendidikan agama islam. Pertama, aspek hubungan manusia dengan Allah SWT. Kedua, aspek hubungan manu- sia dengan sesamanya. Ketiga, aspek hubun- gan manusia dengan alam.

Penelitian ini tergolong penelitian pustaka yang bersifat kualitatif, maka data yang digunakan dalam penelitian diperoleh dari dokumen-dokumen atau transkip yang telah ada yang terdiri dari data primer dan data sekunder. Data primer yaitu data yang berupa pemikiranpemikiran Ki Hadjar Dewantara secara langsung yang telah tertuang dalam bentuk tulisantulisan. Misalnya, buku: Ki Hadjar Dewantara, Bagian Pertama: Pendidikan, Cet: 3 Yogyakarta: MLPTS, 2004; Ki Hadjar Dewantara, Menuju Manusi Merdeka, Yogyakarta: Leutika, 2009. Data sekunder yaitu data yang berupa bahan pustaka yang memiliki kajian yang sama yang dihasilkan oleh pemikir lain. Contohnya: Ngalim Purwanto, Psikologi Pendidikan, Bandung: Remaja Rosda Karya, 2011; Muhibbin Syah, Psikologi Pendidikan dengan Pendekatan Baru, Bandung: Remaja Rosda Karya, 2013; Hasan Lunggalung, Asas-asas Pendidikan Islam, Jakarta: Pustaka Al-Husna, 1992; dan Ramayulis, Ilmu Pendidikan Islam, Jakarta: Logos, 2012.

Metode analisis yang digunakan ialah content analysis (analisis isi), yaitu upaya menafsirkan ide atau gagasan mengenai "Belajar" dari seorang tokoh Ki Hadjar Dewantara, kemudian ide-ide tersebut dianalisa secara mendalam dan seksama guna memperoleh nilai positif untuk menjawab masalah krusial pendidikan Islam saat ini. Dalam hal ini analisis ini digunakan untuk menemukan nilai yang ada dalam tulisan karya Ki Hadjar Dewantara.

\section{Konsep Belajar menurut Ki Hadjar Dewantara}

Pendidikan merupakan kunci pembangunan sebuah bangsa. Pendidikan dilakukan melalui usaha menuntun segenap kekuatan kodrat yang dimiliki anak, baik sebagai manusia maupun sebagai anggota masyarakat untuk mencapai keselamatan dan kebahagiaan setinggitingginya". Ki Hadjar Dewantara telah mengungkapkan betapa pentingnya pendidikan. Pendidikan merupakan kunci untuk membangun sebuah bangsa. Didalam pendidikan ada proses belajar yang menentukan hasil dari tujuan pendidikan, maka dari itu Ki Hadjar Dewantara mengungkapkan bahwa belajar harus sesuai dengan cipta, rasa, dan karsa. Untuk menciptakan proses belajar yang baik, maka harus ada perencanaan pembelajaran. Hal-hal yang harus dipenuhi untuk mencapai tujuan adalah memenuhi unsur-unsur belajar. Ki Hadjar Dewantara mengungkapkan Unsur- unsur belajar sebagai berikut.

a. Peserta Didik

Manusia adalah makhluk yang berbudi, sedangkan budi artinya jiwa yang telah melalui batas kecerdasan yang tertentu, hingga menunjukkan perbedaan yang tegas dengan jiwa yang dimiliki hewan. Jika hewan hanya berisikan nafsu-nafsu kodrati, dorongan dan keinginan, insting dan kekuatan lain yang semuanya itu tidak cukup berkuasa untuk menentang kekuatan-kekuatan, baik yang datang dari luar atau dari dalam jiwanya. Jiwa hewan semata-mata sanggup untuk melakukan tindakan-tindakan yang perlu untuk memelihara kebutuhan-kebutuhan hidupnya yang masih sanggat sederhana, misalnya makan, minum, bersuara, lari dan sebagainya." 
Manusia adalah pribadi yang memiliki cipta, rasa, karsa yang mengerti dan menyadari akan keberadaan dirinya yang dapat mengatur, menentukan, dan menguasai dirinya, memiliki budi dan kehendak, memiliki dorongan untuk mengembangkan pribadinya menjadi lebih baik dan lebih sempurna. Ki Hadjar Dewantara mengungkapkan bahwa, setiap manusia yang lahir memiliki sifat bawaan. Hal tersebut juga terdapat dalam teori psikologi, bahwa setiap individu memiliki sifat bawaan yang nantinya akan dikembangkan melalui interaksi di lingkunganya. Tanpa mempertimbangkan aspek umur manusia, karakter peserta didik yang dibawa ke sekolah merupakan hasil dari pengaruh lingkungan. Hal tersebut cukup berpengaruh pada keberhasilan dan kegagalan individu pada masa perkembangan selanjutnya.

b. Pendidik

Menurut Ki Hadjar Dewantara mendidik dalam arti yang sesungguhnya adalah proses memanusiakan manusia, yakni pengangkatan manusia ke taraf insani. Mendidik harus lebih memerdekakan manusia dari aspek hidup batin (otonomi berpikir dan mengambil keputusan, martabat, mentalitas demokratik).

Ki Hadjar Dewantara memberikan beberapa pedoman dalam menciptakan kultur positif seorang pendidik. Semboyan Trilogi pendidikan memiliki arti yang melibatkan seluruh pelaku pendidikan atau guru dan peserta didik adalah: Tut wuri handayani, dari belakang seorang guru harus bisa memberikan dorongan dan arahan. Ing madya mangun karsa pada saat di antara pesetra didik, guru harus menciptakan prakarsa dan ide. Ing ngarsa sung tulada, berarti ketika guru berada di depan, seorang guru harus memberi teladan atau contoh dengan tindakan yang baik.

\section{c. Tujuan Belajar}

Pembahasan mengenai tujuan belajar tidak akan terlepas dari tujuan pendidikan, hal tersebut disebabkan karena belajar merupakan aspek terpenting dalam pendidikan. Oleh karena itu tujuan belajar sama dengan tujuan pendidikan dan tujuan pendidikan identik dengan tujuan hidup manusia. Berikut adalah tujuan pendidikan menurut Ki Hadjar Dewantara.

"Pendidikan adalah tuntunan di dalam hidup tumbuhnja anak-anak. Adapun maksudnja pendidikan jaitu menuntun segala kekuatan kodrat jang ada pada anak-anak itu, agar mereka sebagai manusia dan sebagai anggota masjarakat dapatlah mentjapai keselamatan dan kebahagiaan jang setinggi-tingginya."

Manusia merdeka merupakan tujuan pendidikan Ki Hadjar Dewantara, merdeka baik secara fisik, mental, dan kerohanian. Kemerdekaan pribadi dibatasi oleh tertib damai kehidupan bersama, dan ini mendukung sikap-sikap seperti keselarasan, kekeluargaan, musyawarah, toleransi, kebersamaan, demokrasi, tanggungjawab, dan disiplin. Perlu digaris bawahi bahwa pendidikan menurut Ki Hadjar Dewantara merupakan sebuah tuntunan. Berdasarkan pengerian tersebut tersirat bahwa hasil perkembangan peserta didik terletak di luar kehendak pendidik. Hal tersebut dikarenakan peserta didik adalah makhluk hidup yang dapat berkembang melalui kodrat yang telah dimiliki. Pendidik hanya menumbuhkembangkan kodrat yang telah ada agar peserta didik dapat berkembang dengan baik.

\section{d. Azas Belajar}

Konsep belajar yang diusung oleh Ki Hadjar Dewantara memiliki lima asas antara lain, asas kemerdekaan, asas kodrat alam, asas kebudayaan, asas kebangsaan, dan asas kemanusiaan. Asas tersebut pulalah yang mendasari pendidikan di perguruan taman siswa. Berdasarkan kelima asas tersebut disimpulkan bahwa, belajar menurut ki hadjar dewantara harus dilandasi dengan kemampuam pribadi, sesuai dengan kodrat, tidak bertentangan dengan budaya, toleransi, dan menjaga hak-hak orang lain. Kemerdekaan atau kemampuan pribadi bertujuan agar peserta 
didik dapat leluasa mengembangkan cipta, rasa, dan karsa dalam proses belajar. Kodrat alam bertujuan agar peserta didik tidak melalaikan kewajibanya baik kewajiban terhadap Tuhan, Lingkungan, masyarakat, maupun diri sendiri. Belajar juga harus sesuai dengan budaya tempat agar hasil belajar bisa diterima di lingkungan tempat tinggal. Belajar juga harus sesuai dengan kebangsaan karena peserta didik akan hidup dan berinteraksi dengan masyarakat luas. Peserta didik juga dituntut untuk tidak melanggar dasar hak asasi manusia.

\section{e. Metode Belajar}

Metode belajar yang diusung oleh Ki Hadjar Dewantara adalah metode among. Among memiliki makna menjaga kelangsungan hidup batin peserta didik dengan mendampingi dan mengarahkan. Bukan hanya membiarkan perkembangan batin peserta didik namun juga menjaga agar keadaan batin peserta didik tetap dalam keadaan baik.

Berdasarkan pernyataan tersebut, pendidik berkewajiban mengembangkan peserta didik sesuai dengan karakter peserta didik dan karakter lingkungan budaya setempat. Hal tersebut bertujuan agar peserta didik dapat menguasai diri sendiri. Among methode merupakan pemeliharaan dan perhatian untuk mendapat pertumbuhan anak lahir dan batin sesuai dengan kodrat.

Sistem among menurut Ki Hadjar Dewantara berisi dua dasar, yaitu sebagai berikut.

a. Kemerdekaan sebagai syarat untuk menghidupkan dan menggerakkan kekuatan lahir dan batin, sehingga manusia dapat hidup merdeka (dapat berdiri sendiri).

b. Kodrat alam sebagai syarat untuk menghidupkan dan mencapai kemajuan dengan secepat-cepatnya dan sebaik- baiknya.

Berdasarkan metode belajar yang dikembangkan oleh Ki Hadjar Dewantara di atas, metode pengajaran yang menekankan kepada penyadaran diri dari masing-masing peserta didik. Hal ini dapat dilihat dari tahapan-tahapan yang disampaikan oleh Ki Hadjar Dewantara yang melihatkan pentingnya sebuah tindakan. Peserta didik diajarkan untuk bertindak sesuai dengan pengetahuan yang telah didapatkan. Hal tersebut menjelaskan, kemerdekaan individu merupakan tujuan ahir pendidikan menurut Ki Hadjar dewantara.

Ki Hadjar Dewantara membagi empat tingkatan dalam proses belajar, yaitu sebagai berikut.

a. Taman Indria dan Taman Anak (5-8 tahun)

b. Taman Muda (umur 9-12 tahun)

c. Taman Dewasa (umur 14-16 tahun)

d. Taman Madya dan Taman Guru (umur 17-20)

Berdasarkan teori tingkatan belajar yang dikemukakan oleh Ki Hadjar Dewantara, terdapat empat tahapan pembelajaran. Tahap perkembangan pertama peserta didik dibimbing untuk mengetahui pengertian mengenai kebaikan dan keburukan. Tahap kedua yaitu, setelah mengetahui pengertian mengenai kebaikan dan keburukan peserta didik diajarkan perilaku yang berkenaan dengan baik buruk menggunakan metode pembiasaan. Tahap ketiga, peserta didik dibimbing untuk mengetahui dan mengukur tindakan yang telah dilaksanakan. Tahap keempat, peserta didik dibimbing untuk memahami, menyadari, dan mempertanggungjawabkan perilaku yang telah dilaksanakan oleh peserta didik.

KI Hadjar Dewantara yang menyebutkan bahwa lingkungan belajar terdapat tiga unsur yaitu yang dikenal dengan istilah tripusat pendidikan atau tri sentra pendidikan yang terdiri dari alam keluarga, alam paguron (sekolah) dan alam pemuda (masyarakat). Menurut Ki Hadjar Dewantara keluarga merupakan pusat belajar yang pertama dan utama, dikatakan demikian karena keluarga merupakan tempat belajar pertama kali yang dialami oleh anak. Keluarga 
memberikan dasar-dasar, sikap, dan keterampilan dasar seperti pengetahuan tentang agama. Kemudian sekolah merupakan penerus dari pendidikan keluarga. Pengetahuan yang tidak diberikan oleh keluarga diberikan di sekolah. Sememtara itu, didalam masyarakat mempunyai nilai-nlai sosial budaya dan peraturan-peraturan yang dijunjung tinggi, dihayati, dan diamalkan. Nilai-nilai dan peraturan-peraturan tersebut selalu berubah dan berkembang sesuai dengan keadaan lingkungan pada waktu itu.

Peserta didik dapat melaksanakan proses belajar dalam lingkungan masyarakat melalui interaksi dengan lingkungan sekitar.

Berdasarkan pengertian-pengertian diatas ada tiga lembaga belajar yaitu lembaga informal (keluarga), lembaga formal (sekolah), dan lembaga non formal (masyarakat). Ketiga lembaga tersebut memiliki peran masing-masing. Lembaga informal yaitu keluarga berperan sebagai peletak dasar pengetahuan peserta didik. Lembaga formal yaitu sekolah berperan memberikan pengetahuan dan deskripsi mengenai sains dan pengetahuan lain yang belum didapatkan dalam keluarga. Lembaga non formal yaitu masyarakat berperan sebagai kontrol sosial yaitu sebagai penghalang perbuatan menyimpang peserta didik sesuai dengan adat dan norma yang ada. Ketiga lingkungan tersebut tidak dapat dipisahkan satu sama lainya karena saling terkait dan mengisi satu kekosongan.

\section{HASIL DAN BAHASAN}

\section{Peserta Didik}

Pada dasarnya peserta didik menurut Ki Hadjar Dewantara sama dengan konsep peserta didik dalam Islam. Apabila ki hadjar dewantara menyebutkan bahwa manusia memiliki sifat bawaan yang diperoleh sejak lahir, maka dalam islam menyebut hal itu dengan sebutan fitrah. Kata fitrah berasal dari kata kerja (fi'il) fathara yang berarti "menjadikan". Secara etimologis fitrah berarti, kejadian, sifat semula jadi, potensi dasar, kesucian. Didalam kamus munjid ditemukan bahwa fitrah mempunyai arti yaitu sifat yang menyifati segala yang ada pada saat selesai diciptakan.

Tingkat kebutuhan peserta didik tidak sama apabila dilihat dari perkembangan usia. Maka dari itu pemberian materi keagamaan harus disesuaikan dengan jenjang usia peserta didik sehingga kebutuhan perkembangan peserta didik dapat terpenuhi dengan baik. Hal tersebut erat kaitanya dengan perkembangan religiusisats peserta didik. Perkembangan religiousitas peserta didik memiliki karakteristik tersendiri. Menurut Clark, seorang anak memiliki sifat Verbalized and Ritualistic yaitu perilaku keagamaan peserta didik, baik yang menyangkut ibadah maupun moral baru bersifat lahiriyah, verbal, dan ritual tanpa keinginan untuk memahami maknanya. Peserta didik memiliki sifat Imitative, yaitu bahwa peserta didik melakukan perilaku sehari-hari merupakan tiruan dari lingkungannya baik berupa pembiasaan ataupun pengajaran yang intensif. Peserta didik sekedar meniru dan melakukan apa yang dilakukan serta diajarkan oleh orang dewasa. Apabila perilaku keagamaan itu dilakukan secara terus menerus dan penuh minat akan membentuk suatu rutinitas perilaku yang sulit untuk ditinggalkan.

Pembagian tahap perkembangan peserta didik, masa remaja menduduki tahap progresif. Dinamika perkembangan rasa agama usia remaja ini ditandai dengan berfungsinya hati nurani. Pada masa remaja ini pula sudah mulai berfikir kritis dan abstrak. Jadi tidak heran apabila masa remaja ini mengalami Religious Doubt. Religious doubt merupakan keraguan rasa agama yang biasanya Allah SWT-lah yang menjadi pokok keraguan. Keraguan rasa agama biasa terjadi pada masa remaja. Akan tetapi gejala religious doubt bisa muncul pada saat usia anak maupun dewasa. Pada masa kanak-kanak bisa terjadi religious doubt dikarenakan pada masa ini 
merupakan masa pencarian keyakinan. Religious doubt yang terjadi terus menerus dan tidak menemukan jawaban akan menimbulkan masalah, salah satunya adalah hilangnya keyakinan. Kajian mengenai tingkatan pembelajaran yang diusung oleh Ki Hadjar dewantara maupun menurut Islam erat kaitanya dengan perkembangan rasa agama. Jika perkembangan tersebut tidak tercukupi sesuai dengan kebutuhan anak maka, akan terjadi kebimbangan pada masa dewasa.

\section{Pendidik}

Pendidik menurut Ki Hadjar Dewantara memiliki arti Tut wuri handayani yaitu dari belakang seorang guru harus bisa memberikan dorongan dan arahan. Ing madya mangun karsa pada saat diantara pesetra didik, guru harus menciptakan prakarsa dan ide. Ing ngarsa sung tulada berarti ketika guru berada di depan, seorang guru harus memberi teladan atau contoh dengan tindakan yang baik. Selain itu pendidik juga harus membimbing peserta didik dengan kasih sayang, sehingga peserta didik dapat leluasa dan bebas mengembangkan ptensi yang ada dalam diri. Antara konsep Ki Hadjar dewantara dan islam sama-sama membimbimg berdasarkan kasih sayang. Hal tersebut membuat peserta didik mampu mengembangkan diri lebih leluasa karena tidak ada tekanan yang dihadapi, sehingga manusia yang merdeka dapat tercapai dengan baik.

\section{Tujuan Belajar}

Tujun belajar Ki Hadjar Dewantara adalah untuk membentuk manusia yang mampu berkembang secara utuh dan selaras dari segala aspek kemanusiaan dan mampu menghargai kemanusiaan setiap orang sehingga, peserta didik dapat berlaku mandiri dan dewasa dalam menjalankan kehidupan dimasyarakat. Pendapat Islam mengemukakan tujuan belajar adalah meningkatkan keimanan melalui pemberian dan pemupukan pengetahuan, penghayatan, pengalaman peserta didik tentang agama Islam, sehingga menjadi manusia muslim yang terus berkembang dalam lingkup yang baik dan nilai-nilai akhlak yang baik.

Tujuan pendidikan agama Islam pada hakikatnya berpusat pada tiga bagian. Pertama, terbentuknya insan kamil yang mempunyai dimensi-dimensi Qur'ani dalam kehidupan. Kedua, terciptanya insan kaffah yang memiliki dimensi-dimensi religius, budaya dan ilmiah. Ketiga, penyadaran fungsi manusia sebagai hamba Allah, khalifah Allah, pewaris Nabi, dan memberikan bekal yang memadai dalam rangka pelaksanaan fungsi tersebut.

Berdasarkan tujuan pendidikan diatas tentu dapat diambil kesimpulan mengenai tujuan belajar, hal tersebut dikarenakan tujuan pendidikan tidak dapat terlepas dari tujuan belajar. Apabila dilihat dari latar belakang pemikiran Ki Hadjar Dewantara, memiliki sifat nasionalis dan memerdekakan. Hal tersebut dikarenakan seting sosial politik pada masa itu merupakan zaman perjuangan dari masa penjajahan. Hal tersebut tentu berbeda dengan pandangan islam, yang mana Islam bertujuan menyadarkan manusia agar berhamba kepada Allah. Ki Hadjar Dewantara lebih ke arah sisi sosial mengenai interaksi manusia dengan manusia yang lain, sedangkan Islam lebih kepada sisi penyadaran dan penerimaan diri terhadap Tuhan. Namun perjuangan untuk merdeka merupakan ibadah, jadi tujuan belajar menurut Ki Hadjar Dewantara tidak bertentangan dengan Islam.

\section{Azas Belajar}

Dasar belajar atau asas yang digagas oleh Ki Hajar Dewantara dalam perguruan taman siswa adalah panca dharma yaitu, asas kemerdekaan, asas kodrat alam, asas kebudayaan, asas kebangsaan, dan asas kemanusiaan. Asas belajar Ki Hadjar Dewantara merupakan bentuk perlawanan pada masa penjajahan. Asas tersebut dibentuk dengan tujuan agar manusia indonesia pada masa itu memiliki keberanian untuk membebaskan diri dari penjajahan. Hal tersebut dapat 
dilihat dari karakteristik point yang lebih bersifat nasionalistik. Berbeda dengan prinsip belajar yang digunakan oleh Islam. Prinsip islam dibentuk berdasarkan pengembangan fitrah manusia. Namun, kedua pendapat tersebut tidak bertentangan dengan pendapat Islam karena, hakikat dari pendapat Ki Hadjar Dewantara ada dalam pendapat Islam.

\section{Metode Belajar}

Metode belajar yang digunakan oleh Ki Hadjar Dewantara adalah metode among. Metode tersebut menempatkan peserta didik sebagai sentral dalam proses belajar. sedangkan islam sendiri memiliki beberapa metode belajar diantaranya yaitu, Metode Teladan, Metode Kisah, Metode Nasihat (Mau'izah), Metode Targhib dan Tarhid. Apabila diterjemahkan metode belajar yang digagas pendidikan islam tidak jauh berbeda dengan gagasan Ki Hadjar Dewantara. Metode belajar dalam Islam juga menghargai kebebasan individu dengan syarat kebebasan tersebut sesuai dengan fitrah. Pada hakikatnya metode belajar yang digunakan oleh Ki Hadjar Dewantara tidak bertentangan dengan pandangan Islam.

\section{Tingkatan Belajar}

Belajar menurut Ki Hadjar Dewantara dan menurut Islam sama-sama mementingkan aspek perkembangan usia. Hal tersebut dikarenakan pengembangan peserta didik harus disesuaikan dengan tingkat kebutuhan. Kebutuhan tiap tingkatan perkembangan manusia berbeda antara satu dengan yang lainya. Hal tersebut yang menyebabkan perhatian terhadap perkembangan usia peserta didik penting untuk diperhatikan. Walaupun sama-sama mementingkan perkembangan usia peserta didik, namun keduanya berbeda tujuan.

Ki Hadjar Dewantara mengembangkan manusia untuk menjadi manusia merdeka, mandiri, dewasa, dan dapat diterima dalam masyarakat dengan baik. Berbeda dengan pandangan Islam yang meningkatkan religiusitas peserta didik agar dapat menjalani kehidupan sesuai dengan syariat Islam. Perbedaanya dikarenakan teori-teori psikologi modern hanya mencakup kehidupan duniawi yang sementara, sedangkan Al-Quran memproyeksikan kehidupan manusia saatini sebagai dasar kehidupan lain yang lebih permanen dan kekal. Manusia akan mengalami transformasi menuju kehidupan lain yang bersifat transedental dan lebih tinggi. Pertumbuhan dan perkembangan manusia dapat berakhir dengan kenikmatan atau penyikasaan. Hal tersebut dapat menjadi alasan berbagai ayat Al-Quran yang menyatakan tahapan perkembangan dikaitkan langsung dengan kehidupan setelah mati.

\section{Lingkungan Belajar}

Lingkungan belajar yang dikembangkan oleh Ki Hadjar Dewantara sama dengan lingkungan belajar yang dikembangkan oleh Islam. Ki Hadjar Dewantara menyebutkan ada tiga lingkungan belajar yaitu keluarga, sekolah, dan masyarakat. Lingkungan belajar Ki Hadjar Dewantara biasa disebut dengan lembaga formal, non formal, dan informal. Lembaga informal yaitu keluarga berperan sebagai peletak dasar pengetahuan peserta didik. Lembaga formal yaitu sekolah berperan memberikan pengetahuan dan deskripsi mengenai sains dan pengetahuan lain yang belum didapatkan dalam keluarga. Lembaga non formal yaitu masyarakat berperan sebagai kontrol sosial yaitu sebagai penghalang perbuatan menyimpang peserta didik sesuai dengan adat dan norma yang ada.

Ketiga lingkungan belajar tersebut merupkan satu kesatuan yang tidak mungkin terpisahkan. Hubungan satu sama lainya saling mengisi kekosongan. Hal tersebut dikarenakan setiap pembelajaran akan tidak mungkin hanya diberikan di sekolah. Pendidikan agama islam juga perlu diberikan sekaligus dikontrol oleh keluarga dan masyarakat. Sehingga pencapaian tujuan tersebut dapat terlaksana dengan baik. 


\section{PENUTUP}

Berdasarkan beberapa materi yang telah dipaparkan diatas, dapat diambil kesimpulan mengenai konsep belajar yang digagas oleh Ki Hadjar Dewantara yaitu Pertama, Konsep belajar yang digagas oleh Ki Hadjar Dewantara merupakan konsep belajar yang memerdekakan peserta didik. Konsep belajar Ki Hadjar Dewantara didasarkan dari sifat bawaan peserta didik yaitu, cipta, rasa, dan karsa. Metode yang digunakan adalah metode among yang memiliki arti menjaga, mendidik, dan membina berdasarkan kasih sayang. Lingkungan belajar harus saling terkait antara lembaga pendidikan didalam keluarga, masyarakat, dan sekolah.

Kedua, Berdasarkan penjelasan tersebut, konsep belajar dalam pandangan Ki Hajar Dewantara relevan dengan Pendidikan Agama Islam. Berdasarkan pengertian-pengertian yang ada, konsep belajar yang dikembangkan oleh Ki Hadjar Dewantara tidak bertentangan dengan pendidikan Agama Islam. Hanya istilah yang digunakannya yang berbeda namun maknanya sama.

Penelitian tentang belajar menurut Ki Hadjar Dewantara jika ditinjau dengan konteks Pendidikan Agama Islam masih jarang dilakukan. Ada dua saran yang ingin peneliti kemukakan sebagai berikut:

Pertama, penelitian ini terkait dengan pengembangan ilmu pengetahuan, diharap kan dapat menjadi dasar berpijak bagi upaya sistematisasi atas upaya Psikologi, terutama yang terkait dengan belajar. Relevansi belajar menurut Ki Hadjar Dewantara dengan Pendidikan Agama Islam setidaknya menjelaskan, bahwa gagasan untuk mencegah output pendidikan yang tidak sesuai, membentuk generasi muda yang lebih baik dari yang sebelumnya dan lain sebagainya. Melalui kajian belajar menurut Ki Hadjar Dewantara ini peneliti membuktikan cara menjaga kualitas pendidikan. Tentu saja usaha peneliti ini dapat dijadikan acuan dalam penelitian berikutnya terkait dengan kemajuan zaman yang semakin berkembang.

Kedua, peneliti menyadari bahwa penelitian ini masih jauh dari kata sempurna, oleh karena itu bagi peneliti berikutnya supaya dapat mengembangkan lebih baik lagi guna menggali nilai-nilai yang terkandung dalam belajar menurut Ki Hadjar Dewantara dan untuk memperkaya kajian tentang konsep belajar. Penelitian tentang belajar menurut Ki Hadjar Dewantara kiranya masih banyak yang belum dikaji, karena manusia selalu berkembang dalam ruang dan waktu, oleh karena itu penelitian tentang belajar menurut Ki Hadjar Dewantara perlu dikaji lebih lanjut.

\section{DAFTAR PUSTAKA}

Dewantara, Ki Hadjar, Bagian Pertama: Pendidikan, Cet: 3 Yogyakarta: MLPTS, 2004. , Menuju Manusia Merdeka, Yogyakarta: Leutika, 2009.

Dimyati dan Mudjiono, Belajar dan Pembelajaran, Jakarta: Rineka Cipta, 2013.

Gafar, Irpan Abd., \& Muhammad Jamil, Reformulasi Rancangan Pembelajaran Pendidikan Agama Islam, Jakarta: Raja Grafindo, 2003.

Idris, Zahara dan Lisma Jamal, Pengantar pendidikan I, Jakarta: PT.Gasindo, 1992.

Jalaludin, Psikologi Agama, Jakarta:PT RajaGrafindo Persada, 2010.

Marimba, Ahmad D., Pengantar Filsafat Pendidikan Islam, Bandung: Al- Ma'arif, 1989.

Nasih, Ahmad Munjin dan Lilik Nur Kholidah, Metode dan Teknik Pembelajaran Pendidikan Agama Islam, Bandung: Rafika Aditama, 2009.

Nata, Abuddin, Metodologi Studi Islam, Jakarta: PT Raja Grafindo Persada, 2012.

Purwanto, Ngalim, Psikologi Pendidikan, Bandung: Remaja Rosda Karya, 2011. 
Ramayulis, Ilmu Pendidikan Islam, Jakarta: Logos, 2012.

Rohman, Arif, Memahami Pendidikan dan Ilmu Pendidikan, Yogyakarta: Laks Bang Mediatama, 2009

Sadiman, Arief S., Media Pembelajaran; Pengertian, Pengembangan, dan Pemanfaatan, Jakarta: Raja Grafindo Persada, 2011.

Singarimbun, Masri, Metode Penelitian Survey, Jakarta: LP3ES, 1989. Slameto, Belajar dan Faktor-Faktor yang Mempengaruhinya, Jakarta: Rineka Cipta, 2003.

Sudjana, Nana, Dasar-Dasar Proses Belajar Mengajar, Bandung: Sinar Baru Algensindo, 2011.

Susilaningsih, Handout Perkembangan Religiousitas Usia Anak, pekuliahan psikologi agama. 